\title{
EVALUATION OF SURFACE ROUGHNESS AND MATERIAL REMOVAL RATE IN ELECTRICAL DISCHARGE MACHINING OF AL-ALLOY WITH $10 \%$ SiC
}

\author{
AbBas FADHIL IBRAHIM \\ Production Engineering and Metallurgy Department, \\ University of Technology, Baghdad, Iraq \\ *Corresponding author: 70011@uotechnology.edu.iq
}

(Received: $18^{\text {th }}$ June 2021; Accepted: $14^{\text {th }}$ September 2021; Published on-line: $4^{\text {th }}$ January 2022)

\begin{abstract}
Aluminum-based metallic matrix compounds are widely used in industrial and aircraft manufacturing due to their advanced characteristics, such as toughness and high strength resistance to weight ratio, etc. Silicon carbide is an important industrial ceramic and it is the fourth hardest ceramic after diamond, boron nitride, and boron carbide. Owing to its low fracture toughness, it is difficult to machine silicon carbide using traditional machining processes. Electrical discharge machine can machine such materials irrespective of their hardness. Aluminum alloy 6061 and $10 \% \mathrm{SiC}$ based-metal matrix composite were used as a workpiece that was produced by stir casting. In the experimental investigation, pulse current $\mathrm{Pc}(10,20$, and $30 \mathrm{~A})$, pulse on (Pon) duration $(100,150$, and $200 \mu \mathrm{sec})$, and pulse off (Poff) duration $(6,12$, and $24 \mu \mathrm{sec})$ were treated as the input variables. The output responses were surface roughness (SR) and material removal rate (MRR). The best value for surface roughness $(\mathrm{Ra})$ reached $(1.032 \mu \mathrm{m})$ at $\mathrm{Pc}$ $(10 \mathrm{~A})$, Pon duration $(100 \mu \mathrm{sec})$ and Poff $(15 \mu \mathrm{sec})$. Also, the best result for the productivity of the process (MRR) reached $\left(69.49 \times 10^{-3} \mathrm{~g} / \mathrm{min}\right)$ at Pc (30 A) Pon, (200 $\mu \mathrm{sec})$ and $(6 \mu \mathrm{sec})$ Poff. Therefore, the experimental outcomes were optimized for surface roughnes and material removal rate by adding $10 \% \mathrm{SiC}$ to aluminum alloy 6061 .
\end{abstract}

ABSTRAK: Sebatian matrik logam berasaskan aluminium telah digunakan secara meluas dalam industri pembuatan dan pesawat kerana ciri-cirinya yang canggih, seperti ketahanan dan daya rintangan yang tinggi kepada nisbah berat, dan lain-lain. Silikon karbida adalah seramik industri yang penting dan ia merupakan seramik keempat terkuat setelah berlian, boron nitrida dan boron karbida. Disebabkan ketahanan frakturnya yang rendah, adalah sukar bagi menghasilkan mesin silikon karbida menggunakan proses pemesinan tradisional. Mesin pelepasan elektrik mampu menghasilkan mesin menggunakan bahan tersebut tanpa mengira kekerasan. Aloi aluminium 6061 dan komposit matrik logam berasaskan $\mathrm{SiC} 10 \%$ telah digunakan sebagai bahan kerja yang terhasil melalui tuangan kacauan. Melalui penyelidikan eksperimen, detik arus Pc (10, 20, dan 30 A), detik hadir (Pon) berdurasi $(100,150$, dan $200 \mu \mathrm{sec}$ ), dan detik henti (Poff) berdurasi $(6,12$, dan $24 \mu \mathrm{sec})$ dirawat sebagai pemboleh ubah input. Respon pengeluaran adalah kekasaran permukaan (SR) dan kadar penyingkiran bahan (MRR). Nilai terbaik bagi kekasaran permukaan (Ra) telah mencapai $(1.032 \mu \mathrm{m})$ pada Pc $(10 \mathrm{~A})$, berdurasi Pon $(100 \mu \mathrm{sec})$ dan Poff $(15 \mu \mathrm{sec})$. Tambahan, hasil terbaik bagi proses produktiviti (MRR) mencapai $\left(69.49 \times 10^{-3} \mathrm{~g} / \mathrm{min}\right)$ pada Pc (30 A) Pon, $(200 \mu \mathrm{sec})$ dan $(6 \mu \mathrm{sec})$ Poff. Oleh itu, hasil eksperimen dioptimumkan bagi permukaan kasar dan kadar penyingkiran bahan dengan tambahan 10\% $\mathrm{SiC}$ ke aloi aluminium 6061 .

KEYWORDS: electrical discharge machining; roughness; material removal; Al-alloy; SiC 


\section{INTRODUCTION}

Electrostatic discharge treatment is one of the most used unconventional manufacturing processes. Thermoelectric power is used to remove the unwanted materials from the workpiece by a sequence of electrical sparks between on the workpiece and the electrode. Electrical discharge happens between the workpiece and the electrode in a small gap that separates the undesirable metal from the original workpiece during melting and evaporation. The work piece and electrode must have electrical conductivity to create the spark [1]. The electrostatic discharge generates an impulse pressure by blasting an insulator to expel the molten particles. Thus, the amount of material removed can be effectively controlled to produce a complex and precise machine element [2]. The removed material is incompletely discarded, and the remaining material collects to form drainage pits. As a result, the machined surface has small pores and cracks caused by a high temperature gradient which reduces the quality of the surface finish. There have been several published studies dealing with the surface finishing of EDM materials. It was observed that several machining parameters affect the surface roughness, and it was difficult to determine the best surface quality that would result from any possible combination of parameters, such as the wear of the workpiece and the wear occurring at the corners of $\mathrm{Gr}$ and $\mathrm{Cu}$ materials observed after the average values of pulse current $(\mathrm{Pc})$ and Pulse on time (Pon). Therefore, the generated sparks were concentrated in the middle of the machined area causing arcing and short circuit. Investigations indicated that the EDM output parameters increased with increasing pulse current, and the best curing rates were achieved using copper and aluminum electrodes [1,3]. The advantage of EDM compared to other traditional methods is the ability to penetrate very hard metals, the ability to machine complex shapes, and the reduction of distortion on fine features $[2,4$, 5].

This technology is widely used to manufacture elements for critical parts, like the copier parts, gearboxes, etc. These components operate under the parameters of temperature and dynamic forces, thus high-strength materials are used, such as thermally hardened steel alloys, titanium-aluminum-tungsten-based alloys and others. Metal Matrix Compounds (MMCs) are compound materials, such as alloys based on $\mathrm{Al}, \mathrm{Mg}$, or $\mathrm{Ti}$ and stiffeners, like $\mathrm{Al}_{2} \mathrm{O}_{3}$ molecules, $\mathrm{SiC}, \mathrm{TiB}_{2}$, and $\mathrm{TiC}$ [6,7]. MMCs provide support to the structure and distribute the load, while the particles or fiber stiffeners provide beneficial thermal performance, physical, or mechanical properties. They have high specific properties, such as light weight, high strength, high toughness, high durability, and excellent heat resistance. The evolution of MMCs leads to their use in the nuclear, aerospace, and automotive industries as an alternative to conventional materials. MMCs are created by different manufacturing processes, such as friction stir welding process, metal injection molding, pressure casting technology, mechanical alloying, and continuous binder powder coating [7,8]. Conventional machines for MMCs offer relatively high engineering precision; therefore, due to the mechanical nature of the process, they generate excessive heat and that causes plastic deformation which in turn reduces the quality of the workpiece surface layer [9-11]. EDM is a contactless process, and the processing powers are humble, therefore it is used for thin, fragile, and aspect ratio machines [12]. Studies showed a selection of process variables, and fixing the appropriate range of parameters to machine every product decides the quality of the product. Haris et al. [13] analyzed the effect of nozzle size and inlet pressure supplied on the flushing efficiency to avoid improper flushing and enhance the material removal rate in the EDM process. Rino et al. [14] investigated the effect of different types of electrode, including $\mathrm{Cu}$ (ordinary electrode) and $\mathrm{Cu}-\mathrm{Ni}$ (newly proposed graphitization catalyst electrode), on 
the electrical discharge machining performance, material removal rate and surface roughness. The copper-nickel electrode recorded a $35 \%$ better material removal rate than the copper electrode, though with a higher short-circuiting rate. Copper-nickel also provided the lowest surface roughness value with $10 \%$ better than the best surface roughness produced by the copper electrode [14]. Abdul-Azeez et al. [15] studied the optimization of parameters for siliconized silicon carbide ( $\mathrm{SiSiC}$ ) on the output quality responses: MRR, tool wear rate (TWR) and SR. Face centered central composite (FCCC) design was used in the experiment planning. Pc and Pon were found to be significant on all the responses. In addition to Pc and Pon, Sv was also significant on MRR. Pc-Pon interaction is significant on MRR and TWR, while Pon-Sv interaction is significant on Ra. [15]. Sulaiman et al. [16] investigated the surface characteristics of a functionally graded Titanium (Ti-6Al-4V) alloy during (EDM). The results showed an average micro-layer thickness of $24.47 \mu \mathrm{m}$ with a current of $7.5 \mathrm{~A}$ when machined at $-1600^{\circ} \mathrm{C}$. Also, an increase in the crack formation with the highest current of $7.5 \mathrm{~A}$ for the surfaces machined at subzero temperature was recorded for both the workpieces and electrode materials [16]. Ahsan et al. [17] studied the effect of nickel powder mixed dielectric fluid on the electrical discharge machining performance of mild steel. Peak current, tool/electrode diameter and concentration of powder were the process parameters. The process performance was measured in terms of material removal rate (MRR), tool wear rate (TWR), and surface roughness (SR). According to them, increasing the current had a negative effect on both the TWR and surface roughness in contrast, and the current increase had a positive effect on the MRR [17]. This study sought to evaluate the effect of the electrostatic discharge mechanism of an aluminum alloy with silicon carbide stiffeners. Peak current, pulse on time, and pulse off time were chosen as process parameters, while the material removal rate and the surface roughness were chosen as process performance indicators.

\section{EXPERIMENTAL WORK}

The work material was made of aluminum alloy matrix (AA6061) and 10\% silicon carbide, which was produced by stirring casting method. Silicon carbide reinforced MMCs have high hardness, low density, high strength (also at high temperature), and high corrosion resistance. Thus, aluminum alloy with silicon carbide parts are used in highly demanding applications (such as pistons and pressure arms). The composite porosity was about $5 \%$, and the average grain size was $50 \mu \mathrm{m}$. The experiment was designed and analyzed using the screening method in Minitab 19 software. Also, three variables of factors, including the pulse current $(\mathrm{Pc})$, pulse on duration (Pon), and the pulse off duration (Poff) were selected for the investigation.

The experimental works were conducted on a CM 323C EDM machine, seen in Fig. 1, with kerosene as the dielectric solution. A copper electrode was used as the tool material in the experimental work with $(\phi 40 \times 100 \mathrm{~mm})$, seen in Fig. 2, with its chemical composition shown in Table 1. According to the design of experiments (DOE) with screening method, the research consisted of thirteen tests. The machining conditions for experimental work are listed in Table 2.

The value of MRR was calculated from the weighting method. The workpiece sample was weighed before machining ( $\left.\mathrm{wp}_{1}\right)$ and after machining ( $\left.\mathrm{wp}_{2}\right)$, and the MRR was calculated from the following formula [18]:

$$
M R R=\frac{W p 1-W p 2}{T}
$$


where, T represents the time of machining. The value of SR of the samples was measured by using a portable device (pocket surf), and the test was carried out in the laboratories of the University of Technology, Baghdad.

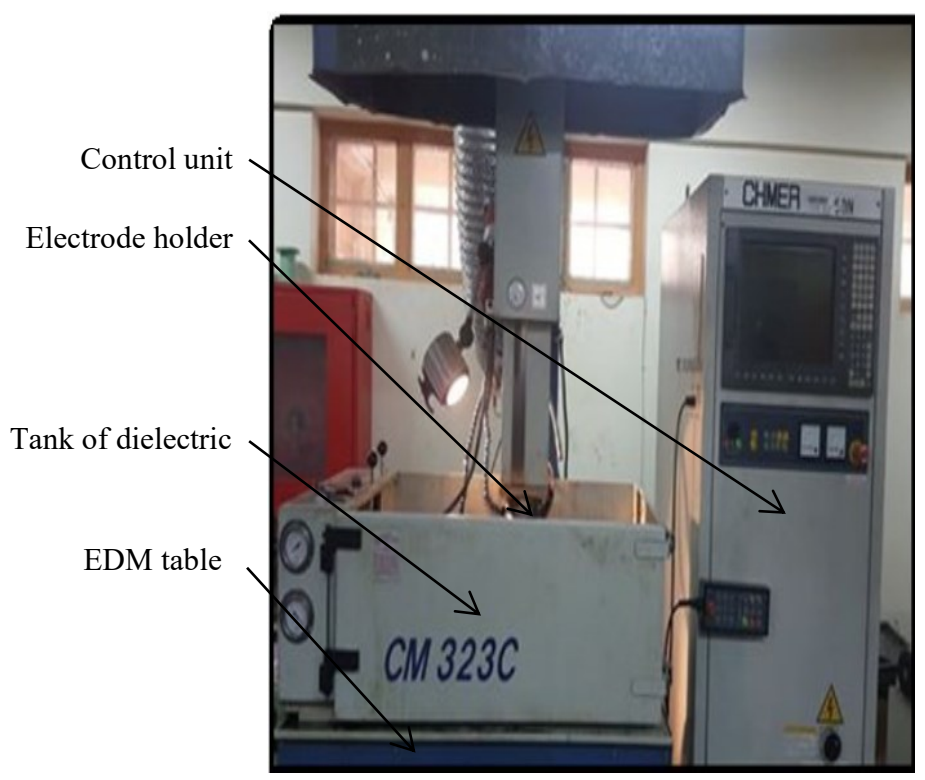

Fig. 1: EDM (CM323C type).

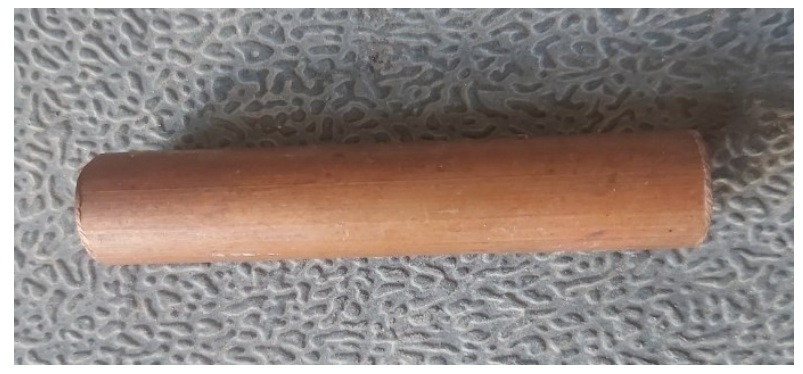

Fig. 2: Copper electrode tool.

Table 1: Chemical composition of copper electrode

\begin{tabular}{rrrrrrrrrr}
\hline Material & $\mathbf{Z n \%}$ & $\mathbf{P b} \%$ & $\mathbf{S n \%}$ & $\mathbf{A u \%}$ & $\mathbf{S i} \%$ & $\mathbf{B i} \%$ & $\mathbf{S b \%}$ & $\mathbf{T e} \%$ & $\mathbf{C u} \%$ \\
\hline Weight\% & 0.0029 & $<0.005$ & 0.003 & 0.0004 & 0.010 & 0.003 & 0.033 & 0.015 & Rem \\
\hline
\end{tabular}

Table 2: Machining conditions for experimental work

\begin{tabular}{lcccc}
\hline Factors of code consideration & Symbol & \multicolumn{3}{c}{ Grade } \\
& & $\mathbf{1}$ & $\mathbf{2}$ & $\mathbf{3}$ \\
\hline Current (A) & Pc & 10 & 20 & 30 \\
Pulse on duration $(\boldsymbol{\mu s})$ & Pon & 100 & 150 & 200 \\
Pulse off duration $(\boldsymbol{\mu s})$ & Poff & 6 & 12 & 24 \\
\hline
\end{tabular}

\section{RESULTS AND DISSCUSION}

Depending upon the experimental results given in Table 3, the effect of the process parameters on the two responses that are (Ra) and (MRR) using copper electrodes was analyzed by analysis of variance (ANOVA) from screening approach with the help of 
MINITAB 19 software. According to the theory of experiment, the research was performed and a response surface full quadratic polynomial was selected.

Table 3: Design of experiments and response result

\begin{tabular}{cccccc}
\hline Run order & Pc $(\mathbf{A})$ & Pon $(\boldsymbol{\mu s e c})$ & Poff $(\boldsymbol{\mu s e c})$ & Ra $(\boldsymbol{\mu m})$ & MRR $\left.\times \mathbf{1 0}^{-3} \mathbf{( g} / \mathbf{m i n}\right)$ \\
\hline $\mathbf{1}$ & 30 & 100 & 6 & 1.543 & 67.45 \\
$\mathbf{2}$ & 10 & 100 & 15 & 1.032 & 58.21 \\
$\mathbf{3}$ & 10 & 150 & 6 & 1.153 & 60.93 \\
$\mathbf{4}$ & 20 & 150 & 15 & 1.384 & 63.71 \\
$\mathbf{5}$ & 10 & 200 & 6 & 1.611 & 59.52 \\
$\mathbf{6}$ & 30 & 200 & 6 & 1.744 & 69.49 \\
$\mathbf{7}$ & 20 & 100 & 6 & 1.226 & 65.36 \\
$\mathbf{8}$ & 10 & 200 & 24 & 1.372 & 63.12 \\
$\mathbf{9}$ & 30 & 150 & 24 & 1.421 & 64.56 \\
$\mathbf{1 0}$ & 20 & 200 & 24 & 1.463 & 64.62 \\
$\mathbf{1 1}$ & 30 & 200 & 15 & 1.711 & 68.28 \\
$\mathbf{1 2}$ & 30 & 100 & 24 & 1.274 & 62.78 \\
$\mathbf{1 3}$ & 10 & 100 & 24 & 1.086 & 58.41 \\
\hline
\end{tabular}

\subsection{Analysis of Variance (ANOVA)}

ANOVA has been used to check the null hypothesis of the predicted data at a point of (95) per cent confidence and to test the defined dominant conditions and the efficacy of the second-order model for increasing the machining process reaction. Fishers statistical test (F-test) tested the importance of the function, its strength. If $p$-value $\leq 0.05$, the factor was concluded to have a statistically significant impact. Tables 4 and 5 indicate the information of analysis of variance for the Ra and MRR of EDM process. The mathematical relation between the variables and the surface roughness and material removal rate was obtained from the non-linear regression models that are given in Eqs. 2 and 3, respectively.

Table 4: Analysis of variance (ANOVA) for Ra

\begin{tabular}{lccccc}
\hline Exporter & $\begin{array}{c}\text { Degree of } \\
\text { Freedom }\end{array}$ & $\begin{array}{c}\text { Adj. Sum. } \\
\text { Square }\end{array}$ & $\begin{array}{c}\text { Adj Mean } \\
\text { Square }\end{array}$ & F-Value & P-Value \\
\hline Model & 4 & 0.57094 & 0.14273 & 21.45 & 0.000 \\
Linear & 3 & 0.55352 & 0.184508 & 27.73 & 0.000 \\
A & 1 & 0.20707 & 0.207072 & 31.12 & 0.001 \\
B & 1 & 0.30276 & 0.302760 & 45.50 & 0.000 \\
C & 1 & 0.04369 & 0.043692 & 6.57 & 0.034 \\
Square & 1 & 0.01741 & 0.017413 & 2.62 & 0.144 \\
B*B & 1 & 0.01741 & 0.017413 & 2.62 & 0.144 \\
Error & 8 & 0.05323 & 0.006654 & $/$ & $/$ \\
Total & 12 & 0.62417 & $/$ & $/$ & $/$ \\
\hline
\end{tabular}

\subsection{Predicted Model of Surface Roughness}

The results for $(\mathrm{Ra})$ response were assessed, which were given in the analysis of variance in Table 4 using the three levels of factors for the backward convert model for the minimum p-value. The F-value Model (21.45) indicated that the model was significant. 
Values of "Prob $>$ F" less than 0.05 imply the model terms are significant. In this case, A, $\mathrm{B}, \mathrm{C}$ were significant model terms. The predicted final empirical equation is:

$$
R a=1.401+0.01439(\text { Pc })-0.00694(\text { Pon })-0.00734(\text { Poff })+0.000035(\text { Pon })^{2}
$$

The 3D graphs presented in Fig. 3, 4, and 5 illustrate the effect of EDM factors on the Ra. Figure 3 manifested that when using pulse current $(10 \mathrm{~A})$ and pulse over duration (100 $\mu \mathrm{s})$, the lower SR was reduced when using copper electrodes and kerosene insulator to $1.032 \mu \mathrm{m}$, and the lower surface roughness occurred due to the interaction effects of low peak Pc and low Pon. The intensity of spark energy increased with Pon, which resulted in recast layers and the formation of large craters on the machined surface tending to increase the surface roughness. Kerosene dielectric produced a better surface finish than that of the distilled water dielectric, possibly due to the slow oxidation rate and the fine surface morphology. Figure 4 depicts the 3D graphs of the Ra using pulse current $(10 \mathrm{~A})$ and pulse duration $(6 \mu \mathrm{s})$, and the lower Ra obtained when using the values of $1.032 \mu \mathrm{m}$. Figure 5 reveals the 3D graphs of Ra using pulse over duration (100) and pulse duration $(24 \mu \mathrm{s})$, and the lower Ra obtained reached the value $(1.086 \mu \mathrm{m})$. This is due to the long pulse duration that furnished good cooling effect and enough time for flushing away the molten material and debris from the gap between the workpiece and electrode.

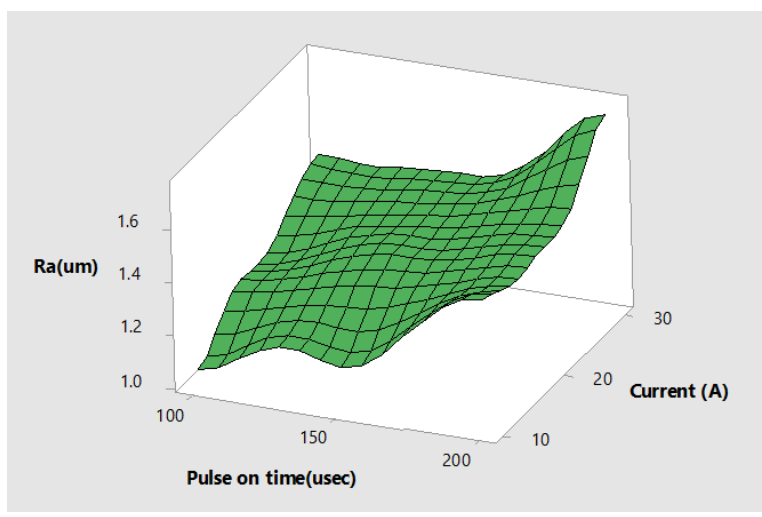

Fig. 3: 3D plot for relationship between SR, Pc, and Pon.

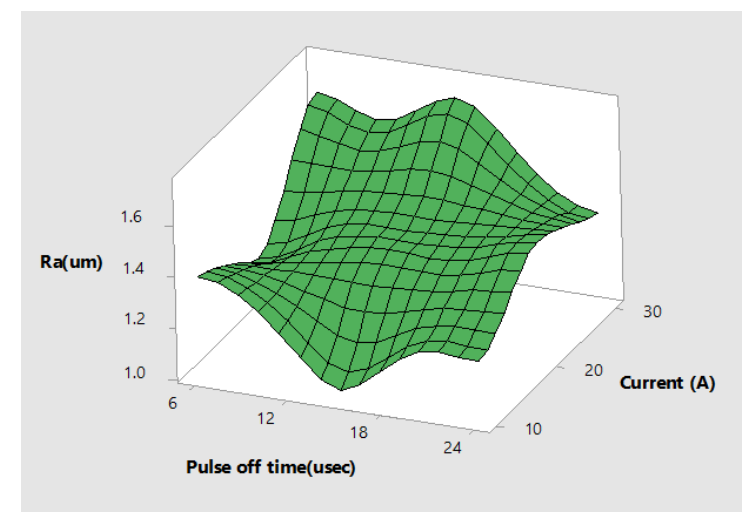

Fig. 4: 3D plot for relationship between SR, Poff, and Pc.

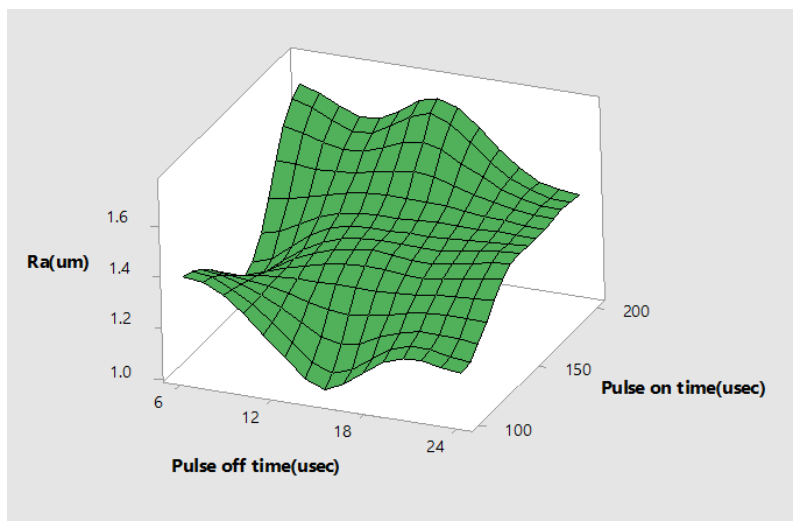

Fig. 5: 3D plot for relationship between SR, Poff, and Pon.

\subsection{Predicted Model of MRR}

In order to assess the outcomes of the material removal rate response in Table 5 using the three levels of parameters, the F-value of 40.66 indicated that the pattern is significant. 
In this case, A, B, C, AC, BC were important model terms. The expected final empirical equation is:

$$
\begin{aligned}
& M R R=56.32+0.5035(\text { PC })-0.0085 \text { (Pon) }-0.204 \text { (Poff) }-0.01199(\text { PC *Poff })+ \\
& 0.002276\left(\text { Pon }^{*} \text { Poff }\right)
\end{aligned}
$$

In Eqs. 2 and 3, it was also apparent that the coefficient of current amplitude was the most significant machining parameter and influence on the predicted (Ra) and (MRR), respectively. Higher pulse current values created melted craters on the surface of the workpiece, visible to the naked eye.

Table 5: Analysis of variance (ANOVA) for MRR

\begin{tabular}{lccccc}
\hline Exporter & DF & Adj SS & Adj MS & F-Value. & P -Value \\
\hline Model & 5 & 151.914 & 30.383 & 40.66 & 0.000 \\
Linear & 3 & 129.792 & 43.264 & 57.89 & 0.000 \\
A & 1 & 104.782 & 104.782 & 140.21 & 0.000 \\
B & 1 & 16.435 & 16.435 & 21.99 & 0.002 \\
C & 1 & 8.575 & 8.575 & 11.47 & 0.012 \\
2-way interactions & 1 & 22.122 & 11.061 & 14.80 & 0.003 \\
$\mathbf{A}^{*} \mathbf{C}$ & 1 & 8.732 & 8.732 & 11.68 & 0.011 \\
B*C & 1 & 7.864 & 7.864 & 10.52 & 0.014 \\
Error & 7 & 5.231 & 0.006654 & $/$ & $/$ \\
Total & 12 & 157.145 & 0.747 & $/$ & $/$ \\
\hline
\end{tabular}

The three-dimensional diagrams presented in Fig. 6, 7, and 8 were used to evaluate and interpret the experimental group model. These numbers demonstrated the influence of EDM factors on the MRR. Figure 6 displays that the value of material removal rate increases with increasing Pc (up to $30 \mathrm{~A}$ ) and Pon (up to $200 \mu \mathrm{sec}$ ) reaching the value of $69.49 \times 10^{-3} \mathrm{~g} / \mathrm{min}$, due to higher Pc, which produces maximum spark discharge power combined with higher thrust in the spark gap, which tends to heat the workpiece and cause melting and vaporization resulting in higher material removal rate. An increase in Pon proportionally increases the spark or the amount of heat energy to transfer heat to the workpiece, which causes the melting of material resulting in higher MRR. Figure 7 shows the 3D graphs of MRR using current (30 A) and pulse duration $(6 \mu \mathrm{sec})$, and the maximum material removal rate obtained when using the value of $69.49 \times 10^{-3} \mathrm{~g} / \mathrm{min}$, due the interaction between maximum current and lower pulse duration. Figure 8 clarifies the 3D graphs for MRR using the Pon (200) and Poff (6 $\mu \mathrm{sec})$, and the maximum material removal rate obtained when using the kerosene dielectric reached the value of $69.49 \times 10^{-3}$ $\mathrm{g} / \mathrm{min}$. MRR increased after the increasing of pulse on time value due the increased energy density at the points of the electrical discharge instantaneously after the time of the discharge, and as a result, the plasma channel expanded continuously with the Pon.

The amount of heat energy generated was large and increased the dissolving and abrasive treatment to remove the successive layers from the surface of the workpiece, and this means that the productivity increased with the current and the pulse on time. 


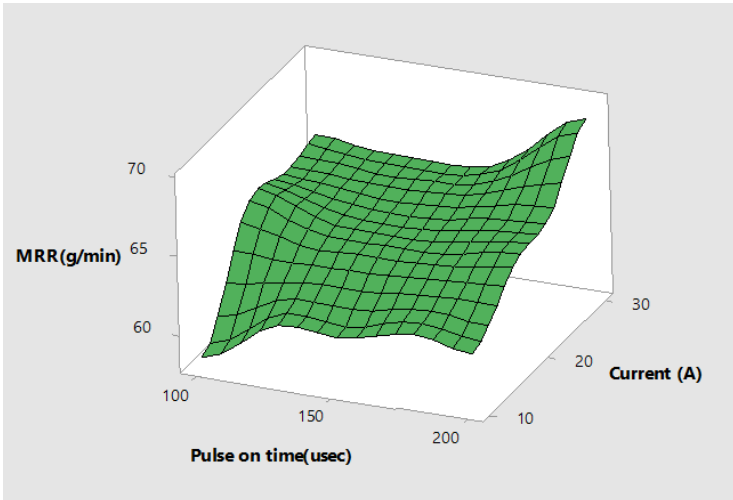

Fig. 6: 3D plot for Relationship between MRR, Pc, and Pon.

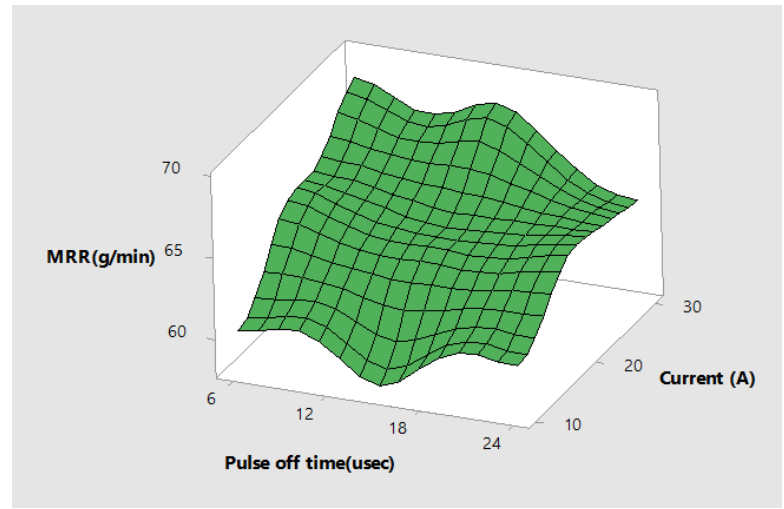

Fig. 7: 3D plot for Relationship between MRR, Pc, and Poff.

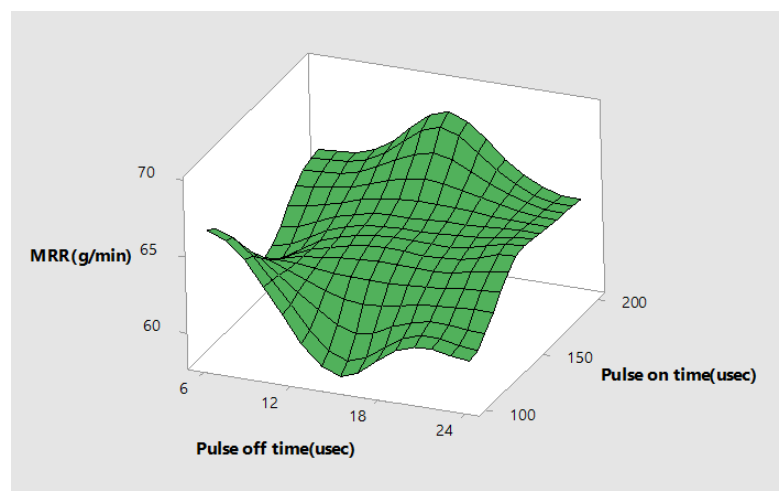

Fig. 8: 3D plot for relationship between MRR, Pon, and Poff.

\section{CONCLUSIONS}

The machining characteristics of Al-alloy with 10\% $\mathrm{SiC}$ MMCs in electrical discharge machining (EDM) were investigated with the help of the screening design method. It was found that the pulse current has a more significant influence on the SR and MRR than the other inputs, namely Pon duration and Poff duration. The values of the coefficients of correlation and the analysis of variance indicated a good statistical analysis for the non-linear regression models of the responses. The best value for the surface roughness $(\mathrm{Ra})$ reached $(1.032 \mu \mathrm{m})$ at pulse current $(10 \mathrm{~A})$, pulse on duration $(100 \mu \mathrm{sec})$ and pulse off $(15 \mu \mathrm{sec})$. The best result for the productivity of the process (MRR) reached $\left(69.49 \times 10^{-3} \mathrm{~g} / \mathrm{min}\right)$ at Pc $(30 \mathrm{~A})$, Pon $(200 \mu \mathrm{sec})$ and Poff $(6 \mu \mathrm{sec})$. The desirability process elucidates that the best predicting response values were roughly the same as those obtained through the experiments as mentioned in the two items above, and this confirmed the results of the present work.

\section{REFERENCES}

[1] Bains P, Sidhu S, Payal H. (2016) Fabrication and machining of metal matrix composites, IKG Punjab Technical University, 31: 553-573.

[2] Pramanik A, Basak K, Littlefair G, Debnath S, Prakash C, Meinam S, Deepak M, Ramesh S. (2020),Methods and variables in electrical discharge machining of titanium alloy - A review, Heliyon, 6: 1-15.

[3] Manjunath P, Sandeep K, Jagadish Danil Y, Khaled G. (2021) Experimental analysis and optimization of EDM parameters on HcHcr steel in context with different electrodes and 
dielectric fluids using hybrid Taguchi-based PCA-utility and CRITIC-utility approaches, Metals, 11(419): 1-23.

[4] Smolentsev V. (1983) EDM and electrochemical methods of processing materials, Moscow: Higher School.

[5] Yeliseyev Y, Savushkin B. (2010) EDM of aerospace products ,Moscow: Moscow State Technical University.

[6] Liao Z., Abdelhafeez A., Li H., Yang Y., Diaza O. G., and Axinte D. (2019) State-of-theart of surface integrity in machining of metal matrix composites, International Journal of Machine Tool Manufacturing, 143:63-91.

[7] Kandpal B, Kumar J, and Singh H. (2014) Production technologies of metal matrix composite: A review, International Journal of Research in Mechanical Engineering \& Technology, 4(2): 27-32.

[8] Manikandana K, Ranjithkumarb P, Kumarb D, Palanikumarc K. (2020) Machinability evaluation and comparison of Incoloy 825, Inconel 603 XL, Monel K400 and Inconel 600 super alloys in wire electrical discharge machining, Journal of Material Research and Technology, 9(6): 12260-12272.

[9] Uthayakumar M, Kumaran T, Khan A, Skoczypiec S, Bizon W. (2018) Microdrilling of AA (6351)-SiC-B4C composite using hybrid micro-ECDM process, Journal of Testing and Evaluation, 48(4): 3073-3086. https://doi.org/10.1520/JTE20180216.

[10] Gore S, Patil G. (2018) Wire electro discharge machining of metal matrix composites: A review. Procedia Manufacturing, 20:41-52.

[11] Skoczypiec S, Machno M, Bizon W. (2015) The capabilities of electrodischarge microdrilling of high aspect ratio holes in ceramic materials, Management and Production Engineering Review, 6(30):61-69.

[12] Sivasankar S, Jeyapau R. (2012) Application of grey entropy and regression analysis for modelling and prediction on tool materials performance during EDM of hot pressed $\mathrm{ZrB} 2$ at different duty cycles, Procedia Engineering, 38:3977-3991.

[13] Haris R, Rasidi I, Kee M, Al Emran I, Zulafif R, Worapong S. (2020) Design and investigate of flushing system for electrical discharge machining (EDM) application, International Journal of Integrated Engineering, 12(2):218-225.

[14] Rino A, Ahmad M, Rahim M, Rha H, Sabri A, Aziz N, Ahmad T, Al Emran I, Rasidi I. (2020) The influence of graphitization catalyst electrode in electrical discharge machining of polycrystalline diamond-finishing condition. International Journal of Integrated Engineering, 12(2):211-217.

[15] Abdulazeez A, Jafri R, Ahmad A, Hamidon M. (2017) Optimization of electrical discharge machining parameters of SISIC through response surface methodology. Jurnal Teknologi, 799(1):119-129.

[16] Sulaiman A, Ahsan K, Mohamed K. (2018) Analysis of microlayer defects of a functionally graded titanium alloy by electrical discharge machining, Engineering and Applied Science Research, 45(1):17-22.

[17] Ahsan K, Muataz F, Mohiuddn A, Nurfathhah A, Mohd D. (2018) Performance of electrical discharge machining (EDM) with nickel added dielectric fluid. IIUM Engineering Journal, 19(1):215-222.

[18] Prasanna J, Rajamanickam S, Amit K, Karthick G, Sathya V. (2017) MRR and TWR evaluation on electrical discharge machining of Ti-6Al-4V using tungsten: copper composite electrode, Frontiers in Automobile and Mechanical Engineering, IOP Conference Series: Materials Science and Engineering, pp. 197-208. 